\title{
ANALYZING THE IMPACT OF TERRORIST ATTACKS ON STOCK INDEX DYNAMICS
}
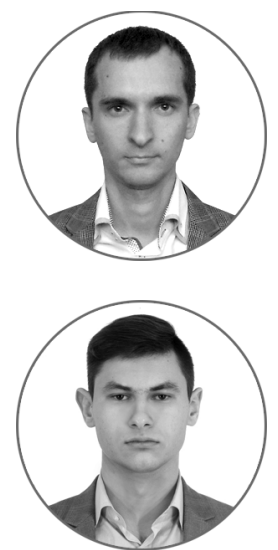

\section{Article history:}

Received 20 January 2017

Received in revised form

6 February 2017

Accepted 20 February 2017

Translated 25 May 2017

Available online 15 June 2017

\section{JEL classification: G14}

Keywords: stock market, stock index, terrorist attack, dynamics, global threat

\section{Sergei N. VOLODIN}

National Research University Higher School of Economics, Moscow, Russian Federation

svolodin@hse.ru

Corresponding author

\section{Andrei G. MIKHALEV}

National Research University Higher School of Economics, Moscow, Russian Federation agmikhalev@edu.hse.ru

\begin{abstract}
Importance The article considers the features of terrorist attacks, which have an impact on stock indices. It analyzes 117 terrorist attacks committed in different countries within 1988-2016.

Objectives The research assesses how terrorist attacks influence stock index trends. It will enable market agents make better decisions and avoid excessive losses, reduce negative reaction of the market in general, and help the national financial system minimize the adverse consequences of terrorist attacks.

Methods We employ historical-logical, graphical, statistical methods and a comparative analysis to describe an impact of different aspects of terrorist attacks on the dynamics of stock indices. We also systematize analytical information in this area.

Results The findings show that the impact of terrorist attacks on stock index dynamics depends on various factors, i.e. the number of victims, level of country's economic development, day of terrorist attack, etc. We found out that the market trend before a terrorist attack had a significant influence on stock index movement after the attack. Terrorist attacks influence industries in a different way.

Conclusions and Relevance Terrorist attacks mostly have a dramatic impact on the dynamics of stock indices. However, the influence is often insignificant and impermanent. Therefore, investors should refrain from ill-judged financial decisions to avoid losses. The findings may be useful for investors, market makers and other market participants.
\end{abstract}

The editor-in-charge of this article was Irina M. Komarova

Authorized translation by Irina M. Komarova

\section{Introduction}

Today's fast moving world often witnesses various economic and political changes. Unfortunately, some of them, indeed, face a strong resistance of various radical groups. Consequently, the number of terrorist attacks and their scale have grown significantly for the recent decades. For example, terrorism caused a nine-fold increase in the number of victims worldwide within 2000 through 2014. Terrorist activities tend to be more intensive in Asia and Africa. Five countries, such as Iraq, Nigeria, Afghanistan, Pakistan and Syria accounted for 78 percent of fatalities from terrorism ${ }^{1}$.

Terrorist attacks become more substantial and devastating. For example, in 2014, acts of terror took

\footnotetext{
${ }^{1}$ Global Terrorism Index 2015. Available at: http://economicsandpeace.org/wp-content/uploads/2015/11/GlobalTerrorism-Index-2015.pdf
} 
place in 93 countries, with 67 of them leaving people injured or killed. 11 countries faced such terrorist attacks that caused over 500 deaths as compared with only five countries in 2013. Furthermore, 10 in 11 countries with the-highest terrorism-related death toll represent regions where massive refugee flows originate, meaning that terrorism may further spread worldwide ${ }^{2}$. The Islamic State of Iraq and the Levant (ISIL) is the most dangerous terrorist organization, which is banned in the Russian Federation. In 2014, ISIL attacks accounted for a half of all the deaths from terrorism. Moreover, the flow of foreigners, who seek to join the organization, with 21 percent of Europeans among them, is increasing. The ISIL was joined by about 7,000 people in the first half of 2015 , while about 25,000 to 30,000 foreign fighters had arrived in Syria and Iraq since the beginning of $2011^{3}$.

Considering the escalating threat of terrorism, it is worth mentioning that terrorist attacks more often than not influence the financial systems of countries. As key indicators of national market trends, stock indices demonstrate the quickest reaction to terrorist incidents. Hence, there is a growing need to understand the entire nature of the impact that terrorist activities have on market trends. Market traders and stock exchange institutions are evidently incapable of predicting attacks of radical groups. However, the understanding of terrorism impact on stock market trends will help them undertake more appropriate measures to mitigate negative consequences of such incidents. This is the objective the article pursues determining the specifics of terrorism impact.

It should be noted that this issue has not been sufficiently elaborated and studied yet. There are few academic researches into this aspect. Very specific publications are also very rare, without covering the overall situation. Several studies into the terrorism impact on stock markets did appear after a series of terrorist attacks that occurred on November 13, 2015 in Paris and on March 22, 2016 in Brussels. However, all of them are based on extremely narrow samples, providing a detailed review of separate cases only. Earlier papers in this field are scarce and mainly examine a certain national market or the economic clout, as a whole. Thus, we decide to analyze the general effect of terrorist activities on markets

\footnotetext{
${ }^{2}$ Global Terrorism Index 2015. Available at: http://economicsandpeace.org/wp-content/uploads/2015/11/GlobalTerrorism-Index-2015.pdf

${ }^{3}$ Ibid.
}

in various countries so that investors, organizers and stakeholders of market trade could properly respond to them. It is certain to cushion the negative effect of terrorist activities not only on financial markets, but also the economy, since the understanding of such effects will help to steer the panic-driven behavior of market actors and take more constructive measures against negative consequences.

\section{Methodology}

For purposes of the research, we gathered and analyzed the information on 117 major terrorist attacks that had occurred for the last 28 years (from 1988 through 2016) in various countries. The statistical sample includes all the countries which suffered from large-scale terrorist attacks, excluding those that are facing civil wars and extreme internal instability. These are primarily counties with the prevalence of the Arabic and African population. The analysis covers the most significant acts of terror, which resulted in over 20 deaths. 73 attacks took place in countries with rather developed stock markets, other than Russia, and 44 cases happened in Russia starting from 1999. Database of Worldwide Terrorism Incidents ${ }^{4}$ and Global Terrorism Database are the sources of information on terrorist attacks ${ }^{5}$. Bloomberg, Eikon, Yahoo Finance and Finam were also used as data sources.

The market reaction to terrorist attacks was determined using national stock market indices of countries, which were selected for the sample, i.e. all the countries for the given period where terrorist attacks took place. Therefore, market indicators included such indices as D\&J-Ind (USA), MICEX (Russia), FTSE-100 (United Kingdom), CAC-40 (France), BSE500 (India), MXTR (Turkey), IBEX 35 (Spain), FTSE MIB (Italy), MERVAL (Argentina), TA-100 (Israel), S\&P/TSX (Canada), Nikkei 225 (Japan), DAX (Germany), ASX 200 (Australia), CSI300 (China), OMXC20 (Denmark), OBX (Norway), BEL20 (Belgium), SOFIX (Bulgaria), OMXS30B (Sweden).

The opening price of the index (when a terrorist attack took place during the trading session) or the closing price of the last trading session were used to register the reaction. The minimum price during the trading session when the terrorist attack happened was regarded as the reaction peak. When the drop continued on the following day, the lowest price of the following trading day was recorded and so on, until the downward market trend ceased. We should

\footnotetext{
${ }^{4}$ Database of Worldwide Terrorism Incidents. RAND, 2009.

${ }^{5}$ Global Terrorism Database 2015. University of Maryland.
} 
also note that the minimum value before growth was considered as the reaction peak when the index fluctuated from falling to rising on the day of the terrorist attack. We thereby managed to exclude an impact of other factors within the day in question. In addition to the evaluation of terrorism impact on market indices, we also analyzed what effect they had on volatility. Hence, we calculated the standard deviation that existed two weeks before a terrorist attack and two days after it.

All events on the terrorist attack day are assumed to be substantially less significant and their effect on the index trend can be mitigated. It is complicated and almost impossible to precisely assess their effect and exclude it, but considering that the terrorist attack is significant for the overall mood of investors, this assumption seems quite plausible.

\section{Analyzing the Terrorism Impact on Trends in Market Prices: Foreign Markets}

Being extremely negative events for the society, terrorist attacks can certainly affect trends in the national stock market too. It is especially true for the most outrageous terrorist attacks causing the biggest number of fatalities.

The 9/11 terrorist attack in the USA is an example. The terrorist attack was so devastating that it even interrupted operations of the stock exchange for six days. The stock market resumed its operations on the seventh day with a 7.1-percent drop in Dow Jones Industrial. The index had been declining steadily for the five following days until it slumped by totally 18 percent and reached its lowest point. It took the stock market 48 days to rebound (Fig. 1).

Another similar case happened on 11 March 2004 in Madrid, where a series of terrorist attacks was committed. As a result, the first trading day saw a-3-percent drop in the index. However, the index kept on falling for the following couple of days (2.8 percent and 4.4 percent respectively). 16 March 2004 in the morning, the index hit its minimum with the total drop of 7.6 percent (Fig. 2). It took 15 days for the index to climb back (until 5 April 2016).

People retain the brightest events. This is also true about terrorist attacks. Therefore, when such events burst out, investors' expectations can often appear too big, considering negative sentiments of the public. Nonetheless, all terrorist attacks do not necessarily lead to dramatic consequences in financial markets.
Recollecting all terrorist attacks, we should mention those, which hardly ever affected market prices and had a slight and short-term effect. After a small fall, the market shrugged off and reached its former indices.

This can be illustrated with the recent series of terrorist attacks that shook Paris overnight from 13 to 14 November 2015. As a response, the CAC 40 index opened the day with 1 percent drop but rapidly regained its former value within 40 minutes. At the end of the trading date, the index exceeded its closing value of the previous session (Fig. 3).

A similar situation was observed in Belgium after terrorist attacks on 22 March 2016. When trading sessions opened on 23 March, the index kept falling within 30 minutes and lost 1.37 percent. However, the market revived and regained its previous positions within two and a half hours (Fig. 4).

It is important for an ordinary investor and other trading agents to understand what dependencies and trade-off of market reactions. Unfolding this issues, we carry out a special statistical analysis so to determine the median market reaction and triggers. Such information will certainly help market actors to make more appropriate decisions in case of terrorist attacks and mitigate adverse effects for each investor and the economy, as a whole.

\section{Analyzing the General and Common Effect of Terrorism on Trends in Market Indices}

Upon the statistical analysis of data, we found a number of common traits reflecting how terrorist attacks influence the market index of the country where they took place. First of all, notwithstanding an extensive and massive public agitation, there was not an overall and entire decline in the stock market, but rather about 60-70 percent. Furthermore, when the index did fall, only a half of cases reported a dip exceeding 1 percent, i.e. so being rather substantial.

It necessitated to evaluate the prior market trend to get assured it was the terrorist attack that caused the drop. If we exclude instances when markets continue its downward trend before the terrorist attack, and consider only opposite situations, we will note the index declined only in 26 percent of cases. So, it means a terrorist attack brake the market trend only in a one forth of cases. It proves, although having big social significance, such events do not have so serious effect on market prices as we could expect from their negative perception. Such situations bring some rational 
attitudes of investors to the surface since they show higher proclivity to respond to economic factors more than social ones, without giving a way to social panic.

As for investors in global markets, such statistics convinces them to abstain from a common scare sentiment after any terrorist attack. First of all, it is reasonable to evaluate recent market trends. If the market tended to grow or remained unchanged, a big collapse should not be expected especially when the terrorist attack was not that devastating. However, when market prices plunged before the terrorist attack, the event can be more damaging. If investors generally have concerns, it might cause a significant market collapse. It is especially true and evident in case of-high-profile terrorist attacks, like the 9/11 terrorist attack in the USA. Then the existing negative trends in-the market were coupled with a dramatic and longstanding drop in prices.

Nevertheless, if we look through statistics of market crashes after terrorism no matter what market trends was previously in place, one third of cases did not demonstrate a meltdown, another one third reduced by 1 percent, and the remaining one third fell substantially by more than 1 percent (Fig. 5).

It is worth mentioning that the stock market becomes more adaptive without responding to terrorist attacks so sensitively. The index has fallen in 60 percent of cases by 1.76 percent on average for the recent 10 years (2006-2016). The index fell in 80 percent of cases by 2.73 percent on average within the period from 1988 through 2005. It may stem from an increasing number of terrorist attacks, thus making investors be more rational and panic-resistant. The same conclusion was made in the research mentioned in reference [1].

During our research, we assessed how market volatility was changing after terrorist attacks. For this we compared the index volatility within two days after the terrorist attacks and two weeks before it. The volatility within the first two days following the terrorist attack exceeded its average value recorded within two weeks (by 41.3 percent) before it in 68.7 percent of cases. The article by K.P. Arin, D. Ciferri, N. Spagnolo notes that terrorist attacks substantially influence stock markets and cause a higher volatility, in particular [2]. We should also note that the national development level also has an impact on the volatility index. In developing economies, 85 percent of cases show that the volatility within the first two days after terrorist attacks exceeds the average volatility recorded two weeks before it, while it is seen only in 58 percent of cases in developed economies. It reveals that investors in emerging economies have more emotional attitude to any terrorist attack. It results in chaotic market prices and proves emerging markets to be more volatile and less resilient to various events. Therefore, investors should have a clear view of the market they operate in, since it strongly correlates with a possible reaction of prices for financial assets.

\section{Factors That Shape the Market Response to Terrorist Attack}

What can help investors and other trading parties to forecast more precisely a market crash as a response to a terrorist attack? There were numerous attempts to evaluate the specifics of their influence depending on various factors. It is necessary to review the general market trends before a terrorist attack to get a more clear picture of the expected market reaction. However, terrorist attacks are very distinct, thus making us to consider how the market might behave afterward.

First of all, we analyze the scale of a terrorist attack, i.e. how many deaths it causes. This parameter is supposed to be the most significant and important for subsequent market reaction. However, our assessments revealed the contrary effect. If we select the ten most devastating acts of terror for the period terrorist attacks are studied, we will definitely see them bringing markets down (2.92 percent on average).

Having analyzed all the cases, rather than the largest ones only, we could not highlight a common correlation between the number of victims and the index trends. Excluding the 9/11 terrorist attack due to its unparalleled significance, the correlation between the number of victims and the index trends accounted for 3.8 percent. Hence, we can conclude that there is a certain threshold of the negative effect terrorist attacks may have on market prices. If we analyze all terrorist attacks, there will be no correlation between the number of victims and subsequent market trends (Fig. 6).

The economic development level of the country becomes another factor we observe. The economic development is measured with Gross Domestic Product (GDP) per capita. Countries are classified into developed and developing ones by their GDP per capita of USD 20,000 (the developed country with the lowest level accounts for USD 29,722 per capita, with USD 12,510 being set for developing countries). 
As the analysis shows, stock markets of developed countries with high GDP per capita (USA, Israel, France) are much more resilient to social unrest. Out of six cases of the biggest index drop, five cases took place in India and Turkey, i.e. the less developed countries in the sample. Furthermore, when the index fell after the terrorist attack, it exceeded a one percent drop in 65 percent of cases in developing countries, while it was common for 50 percent of cases in developed countries. As for the average values in the sample, the index fell by 1.14 percent in developed countries, while it decreased by 1.66 percent in developing ones. If we look at the most significant cases when the market negatively responded to terrorist attacks (more than 1 percent), this drop accounted for 1.71 percent on average in developed countries, while it was 2.74 percent in developing ones. Moreover, when the market growth preceded a terrorist attack, the index endured a drop in 50 percent of cases in developing countries, while it fell in 62.5 percent of cases in developed countries. This definitely indicates that it is not that simple to break existing trends in large developed markets even due to a negative event.

Hence, stock markets of less developed economies are noted to have more dramatic response to terrorist attacks than large and stable economies do. There investors behave more reasonably, without following common turbulence provided that a terrorist attack does not have a strong repercussion upon economic processes in the country. This conclusion is partly made in the research by S. Kumar, J. Liu, where they prove stock indices of smaller economies tend to be considerably responsive to terrorist attacks that happen in larger countries, which are their trade partners [3]. Similar ideas are expressed by G.A. Karolyi, R. Martell [4]. Market liquidity may be another reason. Developed stock markets with high capitalization rate are more difficult to undermine. When the market is developing, it has lower liquidity. Therefore, trends in assets circulating in the market are easier to change, with those changes being more extensive.

As part of our research, we check whether a terrorist attack has a certain effect given it is committed in the country whose citizens it targets at. As we found out, the national stock market is not affected by terrorist attacks aiming at citizens of that country but takes place outside it. Examples include a blast in the center of the Jewish culture in Buenos Aires, Argentina, in 1994, or attacks against the U.S. embassies in Kenya and Tanzania in 1998. All similar cases did not entail any drop in indices at all or caused their slight and short-term correction. We should note, however, that the IBEX35 index decreased by 3.5 percent on December 12. 2015 when the terrorist attack was committed against the Spanish embassy in Afghanistan. But as the market had been already declining rather rapidly within several days, it would be impossible to definitely blame the terrorist attack.

As its important pattern, the market responds to terrorist attack differently depending on a week day. When terrorist attacks take place on working days, 70 percent of cases result in a decline in prices (for all the countries under study). But when terrorist attacks occur on weekend, indices decreased only in 50 percent of cases. It certainly arises from panic-driven behavior of market investors. Should terrorist attacks occur during a trading session, many investors immediately choose to close a long position or open a short one, joining common pessimistic speculations. Should terrorist attacks occur on weekend, the shock will have subdued by the opening of a new trading session and the market will not drop so dramatically.

If we scrutinize this tendency, we detect its predominance in developed countries only. In developed countries, 73 percent of terrorist attacks occurred on working days caused the index to fall, while it happened in 37.5 percent of cases when the terrorist attack happened on weekends. In developing countries, there is no difference for the index trends whether the terrorist attack takes place on working days or weekends. There the market will be affected in 61.1 and 60 percent of cases respectively. It can be explained by the fact that developed markets have more reasonable investors, thus consequences of the emotional shock disappear rather quickly, meanwhile investors in developing markets are generally less seasoned and prone to emotional decisions.

\section{How Quickly Does the Market Rebound After Terrorists Attacks?}

Given the total panic after terrorist attacks, many investors may start selling their securities at low prices and at their own loss. Should they do it? Should they better wait until the drop ceases and the market recovers? To surmount the problem, we studied the average duration of a market drop after terrorist attacks. As the analysis shows, this situation is of short-term nature.

In all the countries under study, the index regained its positions within two weeks in 73 percent of cases 
(Fig. 7). Given index trends before and after terrorist attacks and the upward trend, 9 percent of terrorist attacks prevented the index from reaching its former values within more than two days. So, assuming the upward trend in the market before the terrorist attack, the drop took less than two days in 93 percent of cases. Therefore, if the market was growing before the terrorist attack, investors should wait for the market drop to cease, abstain from selling their assets at low prices, since the market is very likely to revive within a couple of days.

It is worth mentioning that the national development level has no impact on these trends. The extent to which prices fall is the first thing that matters for the recovery period. As proved by statistical data, there is an 80-percent correlation between the number of days it took the index to rebound and the percentage points lost. Moreover, when the recovery process lasted more than three days, the index fell by more than 0.9 percent. According to A.H. Chen, T.F. Siems, the most developed market (USA) recovers after its meltdown more swiftly than markets of other countries [5].

However, even if the drop is sharp, the market needs along period to grow again. For example, after the terrorist attack on 7 July 2005 in London, FTSE-100 fell by 3.63 percent but reached its former positions the following day. A similar situation happened on 25 August 2003 in Mumbai. It took BSE500 one day to climb back after its 5.83 percent drop. As we figured out, when the index drop did not exceed 1.6 percent, then the index returned to its former positions within less than two days in 93 percent of cases. Hence, if the market is on its upward swing or dips insignificantly, it will regain its pre-terrorism positions rather quickly, within two days, in an absolute majority of cases.

As soon as panic and shock subdue, quotations of market assets rise again, since market agents will try to buy instruments that went down in value. So, if a terrorist attack takes place, investors should avoid panic and massive sales. In addition, as mentioned in the research by S. Boubakera, H. Faragc, D.C. Nguyend illustrating the Egyptian stock market for the period from 2003 through 2010, the stocks that had fallen most of all - demonstrated a significant growth. Within a long term (120 days) those stocks generated a higher yield than those that were stable [6]. This effect was stronger in smaller firms, whose stocks lost their positions more dramatically due to their low liquidity. It means that assets that fall most may grow likewise.

In the mean time, as the researchers mention, terrorist attacks do not equally affect various industries, what should be taken into account by investors. For instance, after the terrorist attack on 13 November 2015 in Paris, CAC40 fell by 1 percent, with the value of stocks held by Groupe Eurotunnel S.A., the company from the transportation industry, decreased by 3 percent, hotel group Accor S.A. by 5 percent, Air France-KLM by 6 percent. Thus, companies in the tourism and related sectors (aviation, for example) are the most sensitive to terrorist attacks, provided that tourism accounts for a substantial share in national fiscal revenue. After terrorist attacks shattered France in early January 2015, CAC40 continued growing, without any response to the terrorist attacks. Nevertheless, the tourist flow decreased by 10 percent in two weeks [7], being a definitely negative factor for market prices of stocks pertaining to the civil aviation sector. Terrorism has rather a long-term effect on tourism, up to 13 months from the date of a terrorist attack [8], since the adverse effect lasts for a long time. As a result, investors should understand what stocks they hold. If the stocks pertain to the most vulnerable sectors, the investors should not expect them to appreciate again very quickly up to their former value.

Referring to the air flight industry, we show that share quotations of air companies will slump dramatically within the first days after the terrorist attack, if the terrorist attack involved aircraft. Stocks of national airlines suffer most of all, but the drop is also observed in foreign air companies trading in national stocks exchanges, though to a lesser extent [9]. Notwithstanding the type of air companies, the downward trend can be both of strong short-term and protracted long-term nature [10].

Researchers also point out other sectoral patterns. They say, for example, that oil and gas sector may be specifically exposed to an impact of terrorism. As they particularly note, if terrorist attacks make CAC and DAX go down, they will also significantly affect oil prices [11]. Influencing oil quotations, terrorist attacks echoed in the automobile sector, which is extremely sensitive to fuel prices. If the terrorist attack damages infrastructure facilities, for example, telecommunication networks, it will directly affect banking companies and stock exchanges. As for sectors that depend on consumer demand, shopping centers more often than not lose the former rates of frequentation. People 
do not refuse their shopping plans, but simply postpone them until the panic subdues ${ }^{6}$. Companies of the military-industrial sector demonstrate the lowest sensitivity to terrorist attacks ${ }^{7}$. Terrorist attacks were noted to have even a positive effect on the sector, while they strongly affect the other [12, 13]. Illustrating the 9/11 terrorist attacks, researchers proved terrorist attacks also considerably shattered the insurance sector [14] and the real estate sector [15]. However, although prices for insurance companies' stocks were falling within the first week after the terrorist attack, they resumed their fast growth afterward [16].

Hence, it is possible to say that investors and other trading parties should consider what assets they hold. This will help to make more appropriate decisions and respectively adjust investment strategies and reduce possible losses.

\section{An Impact of Terrorism on Trends in the Russian Stock Market}

Yet, it is very important for the Russian market agents to understand the Russian specifics, rather than global market trends arising from terrorism. In this respect, we review terrorist attacks that take place in Russia starting from the onset of the national stock exchange. The research covers the period from 1999 through 2016 and 44 instances.

Russia's transition to the market relations was accompanied with a great deal of socio-economic problems, thus raising very negative attitudes of the public. As a result, terrorist attacks drastically impaired the financial system. Due to this, terrorist attacks swayed the Russian market in a different way as compared with the other markets worldwide, though the reactions resembled those seen in developing markets, which may include the Russian one.

Given negative sentiments in the society, market prices could fall considerably but recovered more slowly than in other global markets. It was especially evident in case of high-profile terrorist attacks, primarily including the 1999 Russian apartment blasts in Dagestan, Moscow and the Rostov oblast. MICEX index remained unchanged after the first blast (Fig. 8). It may result from the very distant location of Dagestan, and

\footnotetext{
${ }^{6}$ DePillise L. Why Stock Markets Shrug off Terrorist Attacks. The Washington Post, 2016, Mar. 22.

${ }^{7}$ McIntyre D. Terrorism: How Wall Street Responds to Attacks. Investopedia, 2015. Available at: http://www.investopedia.com/articles/07/terrorism.asp
}

the belligerent situation in the region. That is why the terrorist attack was not perceived as something really unexpected. However, the second blast in Moscow undermined the index by 3 percent for two days, though it regained its positions in a day. The negative effect was further accumulated: the third blast made the index fall by 4.3 percent in a day and continued so during the following days by 2.5 percent. After the final terrorist attack burst out, the index dropped by 4.5 percent again and kept on falling within the following three days. The index began growing only on 23 September 1999, but it took it 29 trading days (until 2 November 1999) to reach its former positions before the terrorist attacks.

The Russian market reacted similarly within 13 October and 14 October 2005 to armed actions of the Islamists in Nalchik, Kabardino-Balkar Republic. The index fell by 3.6 percent during the first day but grew by 40 percent during the last trading hour. Next day, the index kept its downward trend and lost 3.8 percent reaching its record low by 21 October 2005, with a 10 percent market meltdown in total. Having hit its record low, the index turned to grow but regained its lost points only within 12 days, 2 November 2005 (Fig. 9).

However, the reaction of the Russian market to terrorism was not so longstanding all the time. For example, when terrorists seized hostages during the musical performance in one of the Moscow theaters and held them from October 23 through October 26, 2012, the MICEX index fell by 2.5 percent on the first day of the siege and by 0.5 percent on the following day. The index climbed back by 2.25 percent on the first day just after the hostages were relieved. The index drop was completely regained on the forth day (Fig. 10).

Likewise it is seen worldwide, the upward trend in Russia is not always undermined as a result of a terrorist attack. The Beslan school siege from September 1 through September 2, 2004 can be another example. The MICEX index started to fall and lost 1.2 percentage points on the first day of the siege. However, whereas there was the upward trend several weeks before the siege, it did not affect the situation considerably, though we cannot by no means deny the tragedy and severity of the siege. The index grew again by the end of the day and completely compensated its drop (Fig. 11). The situation repeated the following day, i.e. the index fell by 1.7 percent but started growing again and reached its former positions in three days after it hit its lowest record. Therefore, 
the robust upward trend almost eliminated the impact of the terrorist attack.

\section{Analyzing How Terrorism Generally Influences the Russian Stock Market}

We analyzed all the acts of terror to evaluate how terrorist attacks basically influenced the Russian stock market trends. Whereas military operations in the Caucasus made the region's situation very different from the situation in the rest of the regions, we selected only those terrorist attacks that happened there and left over 20 people injured or killed.

Having analyzed general statistics, the Russian market responds to terrorist attacks in a very similar way with other developing economies. So, the market set for a decline in 63.6 percent of terrorist attacks for the recent 17 years (60.7 percent of cases in other developing countries). When the index did fall, it lost more than 1 percentage point in 64 percent of cases. This completely coincides with the situation in developing countries, where the index fell by more than 1 percentage point in 65 percent of cases (while it happened so in 50 percent of cases in developed countries). Given the upward trend, the Russian market fell in 62.5 percent of cases, that was completely compliant with developed countries (against 50 percent in developing countries and 59 percent totally worldwide).

As for the mean index trend, it is consistent with similar indicators of developing countries: the MICEX index fell by 1.7 percent on average as a result of the terrorist attack (1.66 percent in all developing countries and 1.14 percent in developed ones), but if we consider only those cases when the index plunged, the drop accounted for 2.7 percent on average (2.74 percent in all developing countries against 1.71 percent in developed countries).

In the mean time, the Russian market demonstrates an absolutely different dependence between the index drop and the day when the terrorist attack occurs as compared with foreign developing markets, being more alike the situation in developed markets. When a terrorist attack takes place on working days in Russia, it undermines the index in 70 percent of cases, but when a terrorist attack is committed on weekends, the index falls only in 40 percent of cases (against 69.1 percent for working days and 50 percent for weekends in all other countries under study). As we show, it does not matter for developing market, the index falls both on working days and weekends in 60 percent of cases. Russia demonstrates trends akin to developed countries, where the index falls on working days and weekends in 73 and 37.5 percent of cases respectively.

Whereas Russia occupies vast areas, it was interesting to check how a terrorist attack in Moscow influenced the market. As the analysis shows, terrorist attacks in Moscow are more influential for the index than those in other regions as it was expected. They caused the market meltdown in 70 percent of cases, and if the index yet decreased, it lost more than 1 percentage points in 80 percent of cases. This trend is not typical of the domestic market only. According to T. Tavor, terrorist attacks in the vicinity of Jerusalem and the central region of Israel are much more substantial for the stock market than those committed in other regions [17]. Investors should definitely regard this in similar situations.

As for the recovery time of the index, it is much longer in Russia than abroad. In Russia, the index returned to its previous positions within two days only in 57 percent of cases as compared with 73 percent abroad. The percentage points lost and the recovery time correlate likewise in other countries. It took the index more than two days to recover only if it fell by more than 0.73 percent. When the drop accounted for 2.5 percent and less, the index regained its positions within two days in 80 percent of cases. These are levels investors should regard as the recovery time after the drop. When the index fell by less than 0.73 percent, the average recovery time took 0.37 day, i.e. the index regained its positions within the first day.

The Russian market was noted to tend statistically to respond with a decline (like foreign markets as well). Although the index more often than not falls after terrorist attacks (67 percent of cases within the period following 2006 against 62 percent within the period from 1999 through 2006), those drops occur to a lesser extent. As seen within the recent 10 years, terrorist attacks cause a 1.2 percent decline in the market, while it decreased about 2 percent on average before. If we consider only those cases when the index falls, this drop will account for 3.3 percent on average within 1999 through 2006 and 1.8 percent within the recent decade. It may result from the absence of large terrorist attacks in the recent decade as compared with the late 1990s, rather than only from stabilization of the market and socio-economic processes in the country. 
We carried out an analysis like we did in relation to foreign markets so to evaluate how terrorism influenced the market volatility. Supplemented with the standard deviation, the sample size for Russia consisted of 31 cases. The index reacted almost in the same way as it did abroad, i.e. the volatility in the first two days after the terrorist attack exceeded the average one recorded within two weeks before it in 64.52 percent of cases $(68.7$ percent of cases in foreign markets). If assessed with this indicator, the Russian market appears to be more sustainable and similar to developed markets (58 percent of cases), rather than developing ones (85 percent of cases). This situation provides evidence that investors in the Russian market are less prone to behave chaotically and emotionally in response to terrorist attacks than investors in other developing markets.

\section{Conclusions}

As the analysis shows, various factors determine how stock indices respond to terrorist attacks. These factors include the number of victims, economic development level of the country, working day or weekend. There we should also consider whether the terrorist attack is carried out within or outside the country, whose citizens are targets of the terrorist attacks, in the capital or elsewhere. The general market trend before the terrorist attack is also very important. If the market was growing, the terrorist attack affected the market less than it did under the downward trend.

As for the situation in Russia, the Russian market responds to terrorist attacks like developing markets since it has a deeper reaction and sees a decline in quotations. The severe economic situation in the late 1990s often resulted in a retarded market recovery as compared with foreign markets, thus influencing general market indicators substantially. Today the socio-economic situation in Russia is stable and lets us hope the market will not react to terrorist attacks dramatically. The Russian market has not demonstrated so negative reactions for the recent decade, thus proving the above assumption.

However, if we assess some parameters of the Russian market, we would trace the trends seen in foreign markets. For example, when the terrorist attack is carried out on working days, thus hypothetically pushing panic-stricken investors to urgently sell their stock assets, the investors started to behave reasonably and rationally again within one or two days. So, the Russian market completely matches the way developed markets react when terrorist attacks occur on working days. The nature of market volatility after the terrorist attack is another parameter. The volatility of the Russian market provides evidence of the more stable reaction to any terrorist attack, thus making the situation predictable and foreseeable. In this respect, the Russian market resembles developed markets more than developing ones.

Having analyzed the global stock markets, we formulate some recommendations for investors and other trading agents. First of all, when any terrorist attack occurs, investors should not embark on massive sale of their stock assets, if it is ignited by the terrorist attacks. They'd better wait until the market turmoil subdues. In most cases, the market will recover within the coming two days. Investors should definitely abstain from sales, if there has been the general market growth for the recent several days and more. When the terrorist attack is much larger, it may take the market more days to rebound. But still after the market panic ceases, the market will revive as expected through massive purchases of quickly devalued assets. To respond more reasonably to terrorist attacks in terms of their trading strategy (marginal leverage ratio, approximation of stop loss premiums, use of derivatives, etc.), investors should consider the factors, which shape the way the market will be falling and how quickly it will recover. Higher precaution is advisable for those investors who hold securities of issuers operating in the industries that are directly affected by the terrorist attack. In such cases, the recovery of prices may be extremely protracted.

It is worth mentioning that markets will stabilize so long as investors understand the specifics of the market reaction to terrorist attacks. Assuming that prices will be falling for a short period of time after the terrorist attack, other than the rarest and especially large instances, many investors will prefer to wait for the market panic to pass and abstain from selling their assets at lower prices. It will offset the drop and prevent its further propagation, thus mitigating consequences for the national market as a whole. Hence, fewer market agents will incur losses, and terrorism issues will not be aggravated with a chaos and meltdown in financial markets. This will certainly alleviate such situations for any national economy. 


\section{Figure 1}

Dynamics of the Dow Jones Industrial Average Index in September-November 2001

12000

10000

8000

6000

4000

2000

0

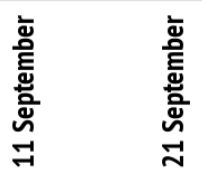

Source:Authoring based on Finam. Available at: http://www.finam.ru/profile/mirovye-indeksy/d-j-ind/export

\section{Figure 2}

Dynamics of the IBEX35 Index in March-April 2004

\section{0}

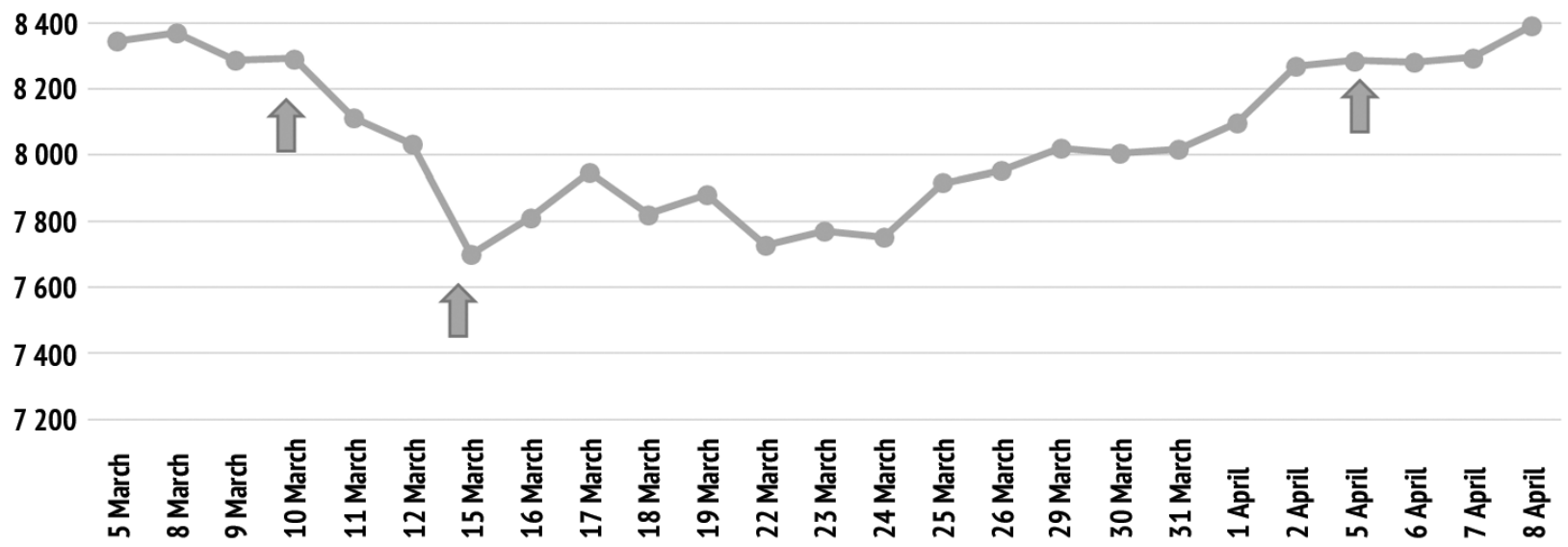

Source:Authoring based on Bloomberg Terminal 
Figure 3

Dynamics of the CAC 40 Index on November 16, 2015

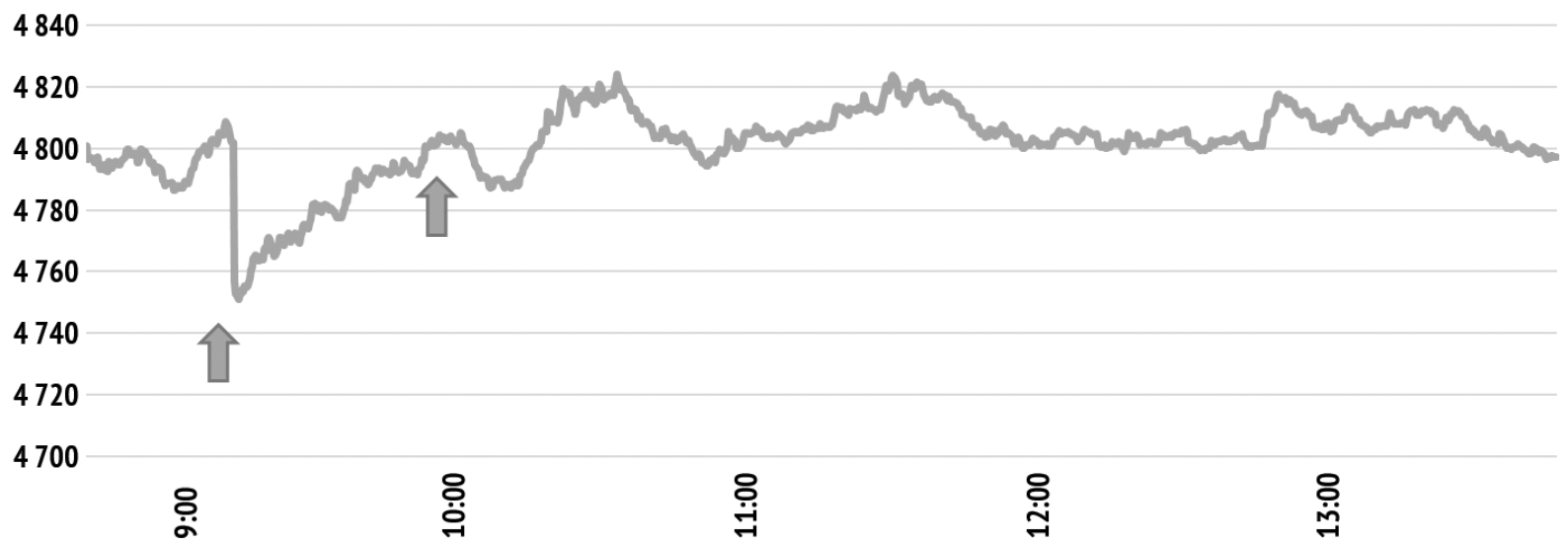

Source:Authoring based on Bloomberg Terminal

Figure 4

Dynamics of the BEL20 Index on March 22-23, 2016

3430

3420

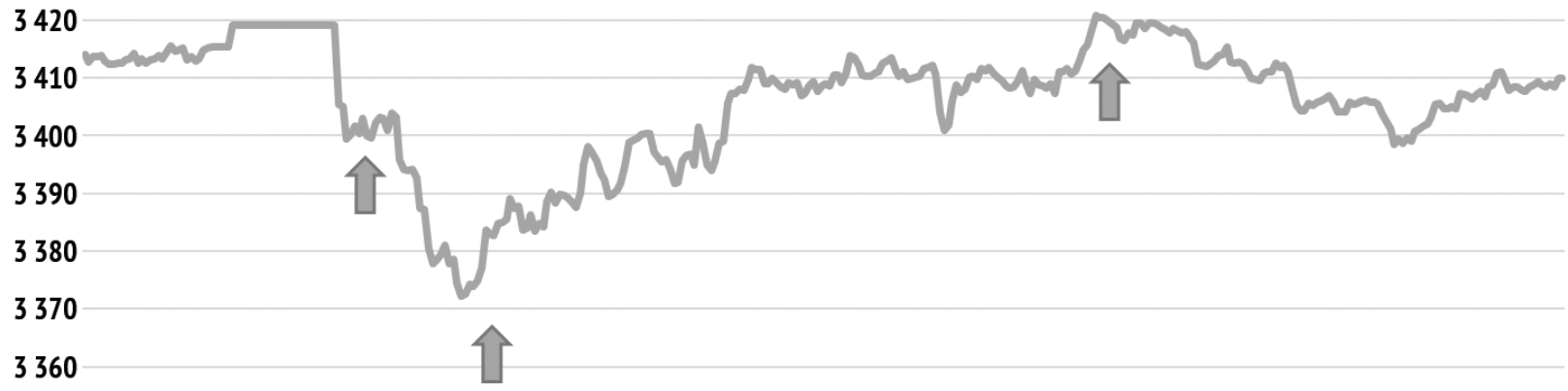

3350

3340

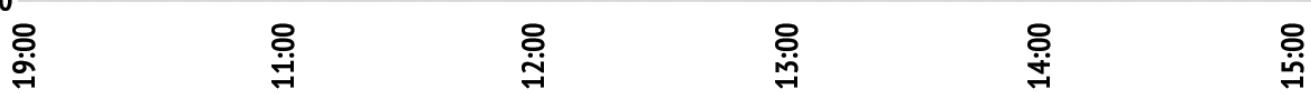

Source: Authoring based on Eikon Financial Analysis, Thomson Reuters 


\section{Figure 5}

A drop in stock index after a terrorist attack

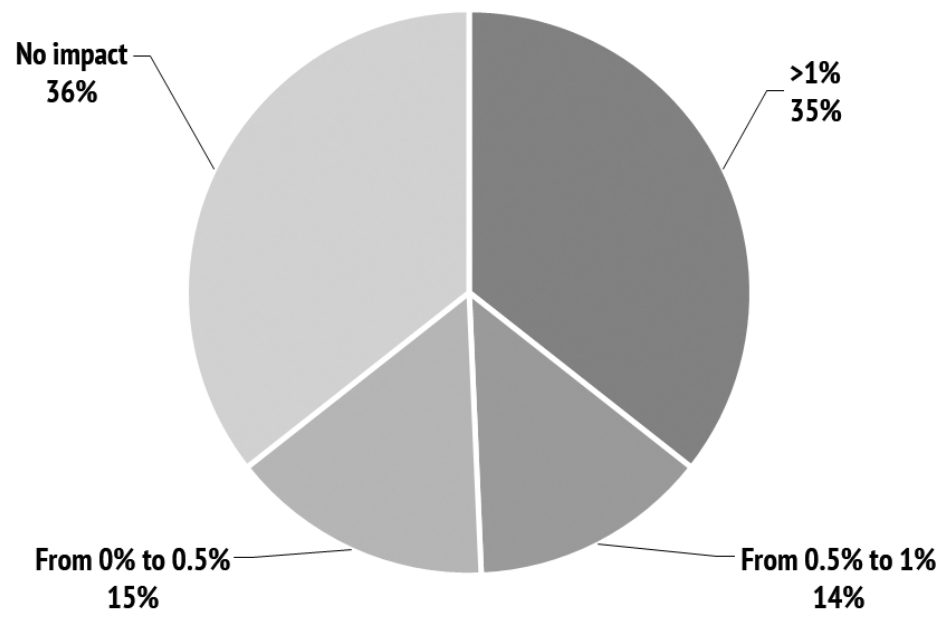

Source: Authoring based on Finam, Bloomberg Terminal, Eikon Financial Analysis, Thomson Reuters

\section{Figure 6}

Correlation between a drop in stock index and number of victims (excluding 9/11)

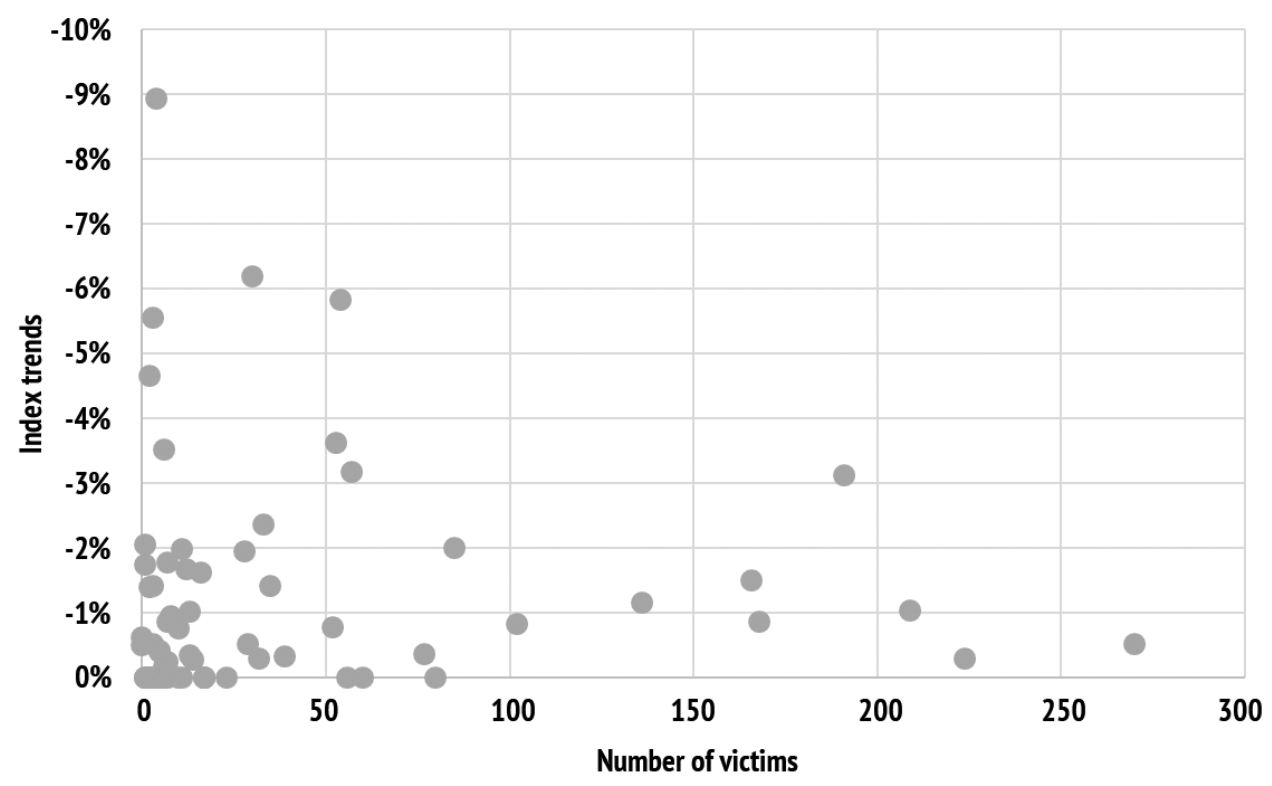

Source: Authoring based on Finam, Bloomberg Terminal, Eikon Financial Analysis, Thomson Reuters 


\section{Figure 7}

Number of days to reach pre-terrorist attack values

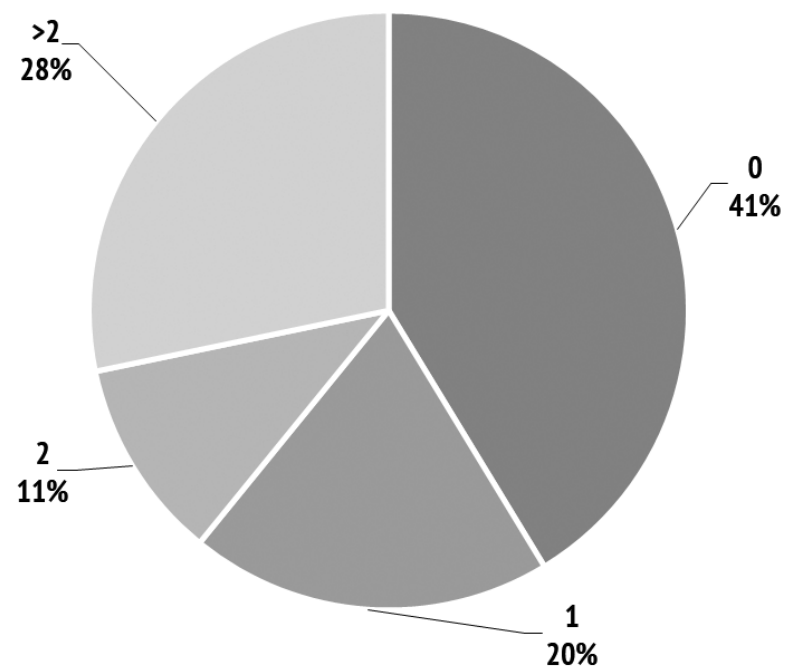

Source: Authoring based on Finam, Bloomberg Terminal, Eikon Financial Analysis, Thomson Reuters

\section{Figure 8}

Dynamics of the MICEX Index in September-November 1999

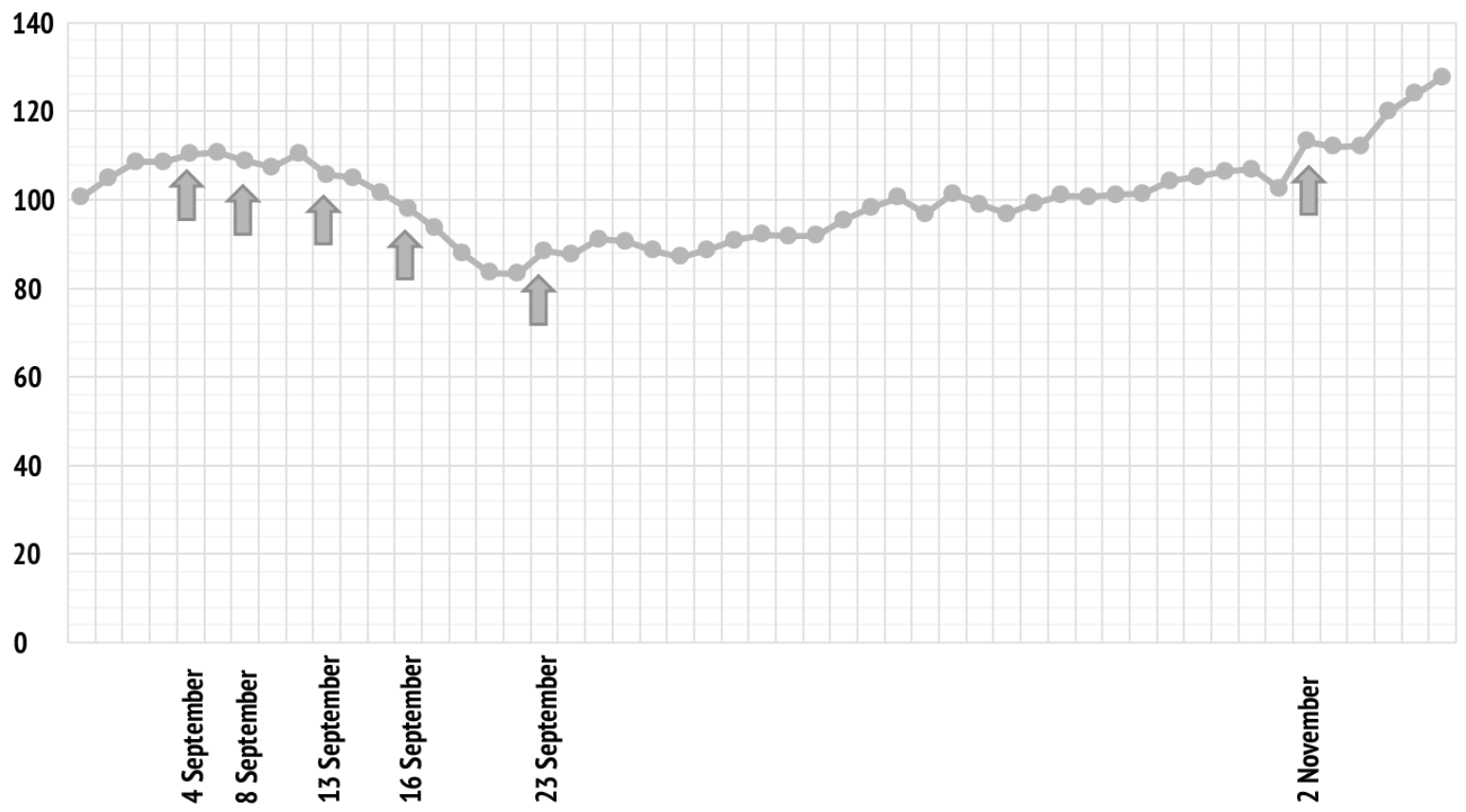

Source:Authoring based on Finam. Available at: http://www.finam.ru/profile/mirovye-indeksy/micex/export 
Figure 9

Dynamics of the MICEX Index in October-November 2005

950

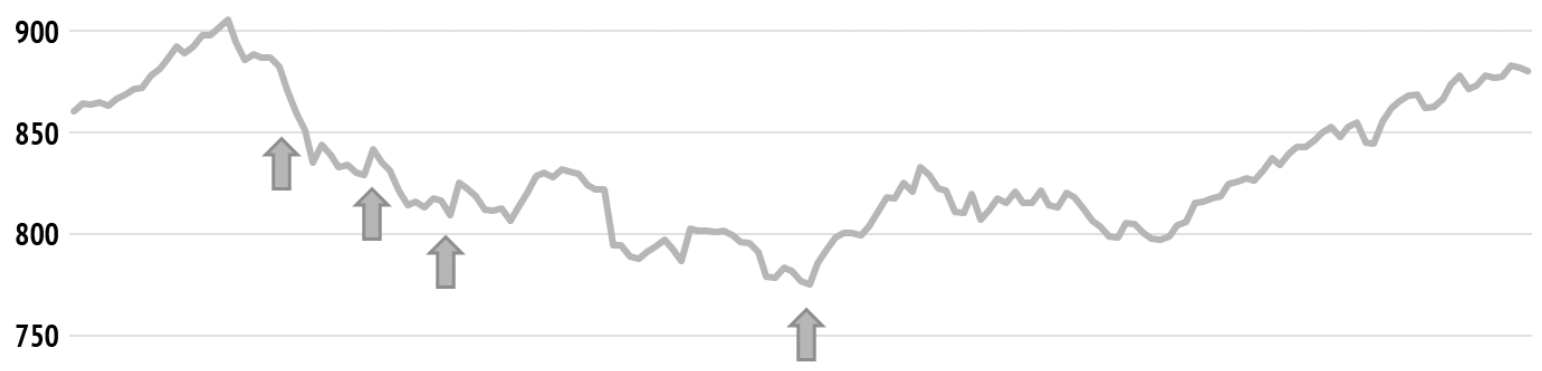

700

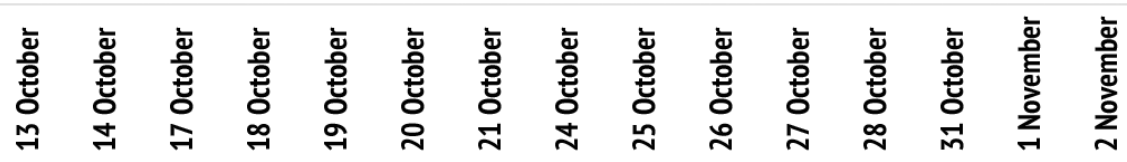

Source:Authoring based on Finam. Available at: http://www.finam.ru/profile/mirovye-indeksy/micex/export

\section{Figure 10}

Dynamics of the MICEX Index in October 2002

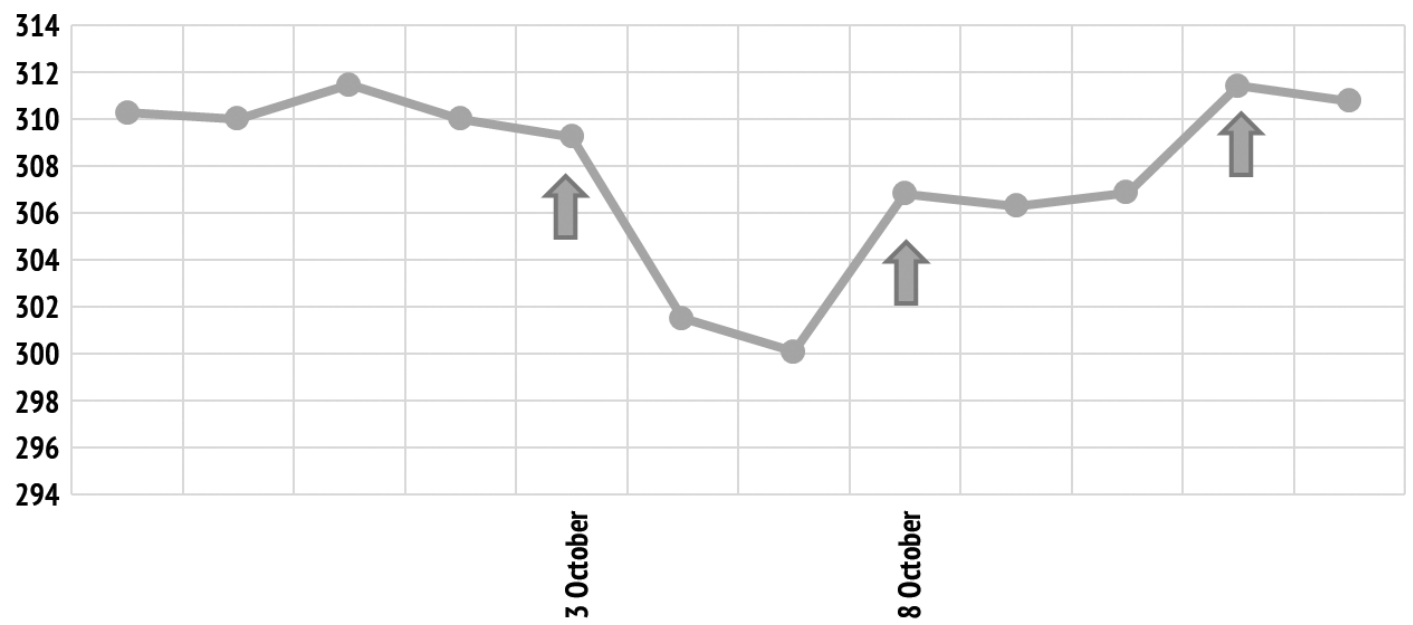

Source:Authoring based on Finam. Available at: http://www.finam.ru/profile/mirovye-indeksy/micex/export 


\section{Figure 11}

Dynamics of the MICEX Index in August-September 2004

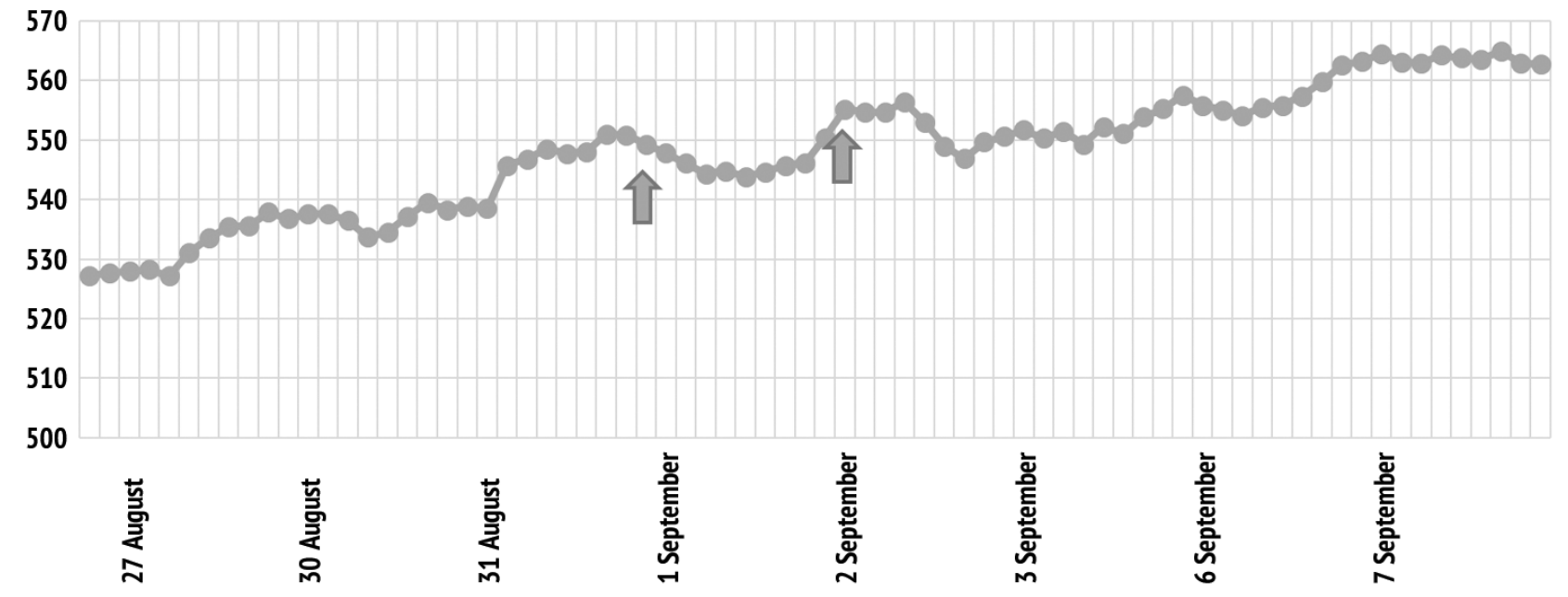

Source: Authoring based on Finam. Available at: http://www.finam.ru/profile/mirovye-indeksy/micex/export

\section{References}

1. Shell A. Terror Attacks Don't Shock Stocks for Long, History Shows. USA Today, 2016, March 22.

2. Arin K.P., Ciferri D., Spagnolo N. The Price of Terror: The Effects of Terrorism on Stock Market Returns and Volatility. Economics Letters, 2008, vol. 101, iss. 3, pp. 164-167.

Available at: https://doi.org/10.1016/j.econlet.2008.07.007

3. Kumar S., Liu J. Impact of Terrorism on International Stock Markets. Journal of Applied Business and Economics, 2013, vol. 14, iss. 4, pp. 42-60.

4. Karolyi G.A., Martell R. Terrorism and the Stock Market. International Review of Applied Financial Issues and Economics, 2010, vol. 2, iss. 2, pp. 285-314.

5. Chen A.H., Siems T.F. The Effects of Terrorism on Global Capital Markets. European Journal of Political Economy, 2004, vol. 20, iss. 2, pp. 349-366. Available at: https://doi.org/10.1016/j.ejpoleco.2003.12.005

6. Boubaker S., Farag H., Nguyen D.K. Short-term Overreaction to Specific Events: Evidence from an Emerging Market. Research in International Business and Finance, 2015, vol. 35, pp. 153-165. Available at: https://doi.org/10.1016/j.ribaf.2014.10.002

7. Lemarechal C., Mang E., Maniere E., Ramic A. The Terrorist Attacks, a Problem for the Tourism Industry in France? Available at: http://www.tourmag.com/The-terrorist-attacks-a-problem-for-the-tourism-industry-inFrance_a71934.html

8. LaGrave K. How Terrorism Affects Tourism. Available at: http://www.cntraveler.com/stories/2016-03-31/howterrorism-affects-tourism

9. Carter D., Simkins B. The Market's Reaction to Unexpected, Catastrophic Events: The Case of Airline Stock Returns and the September 11 th Attacks. The Quarterly Review of Economics and Finance, 2004, vol. 44, no. 4, pp. 539-558. Available at: https://doi.org/10.1016/j.qref.2003.10.001

10. Ito H., Lee D. Assessing the Impact of the September 11 Terrorist Attacks on U.S. Airline Demand. Journal of Economics and Business, 2005, vol. 57, iss. 1, pp. 75-95. Available at: https://doi.org/10.1016/j.jeconbus.2004.06.003

11. Kollias C. et al. The Effects of Terrorism and War on the Oil and Prices - Stock Indices Relationship. Economics of Security Working Paper, 2011, no. 57. 
12. Berrebi C., Klor E. The Impact of Terrorism Across Industries: An Empirical Study. CEPR Discussion Papers, 2005, no. 5360. Available at:

https://www.researchgate.net/publication/4758100_The_Impact_of_Terrorism_Across_Industries_An_Empirical_ Study

13. Berrebi C., Klor E. The Impact of Terrorism on the Defense Industry. Economica, 2010, vol. 77, iss. 307, pp. 518-543. Available at: https://doi.org/10.1111/j.1468-0335.2008.00766.x

14. Doherty N.A., Lamm-Tennant J., Starks L.T. Insuring September 11th: Market Recovery and Transparency. Journal of Risk and Uncertainty, 2003, vol. 26, iss. 2-3, pp. 179-199. Available at: https://doi.org/10.1023/A:1024161808231

15. Kallberg Jarl, Liu Crocker, Pasquariello Paolo. Updating Expectations: An Analysis of Post-9/11 Returns. Journal of Financial Markets, 2008, vol. 11, iss. 4, pp. 400-432. Available at: https://doi.org/10.1016/j.finmar.2008.01.006

16. Wang Y., Corbett R.B. Market Efficiency: Evidence from Market Reactions of Insurance Industry Stocks to the September 11, 2001 Event. Journal of Insurance Issues, 2008, vol. 31, iss. 2, pp. 152-167.

17. Tavor T. The Impact of Terrorist Attacks on the Capital Market in the Last Decade. International Journal of Business and Social Science, 2011, vol. 2, iss. 12, pp. 70-80.

\section{Conflict-of-interest notification}

We, the authors of this article, bindingly and explicitly declare of the partial and total lack of actual or potential conflict of interest with any other third party whatsoever, which may arise as a result of the publication of this article. This statement relates to the study, data collection and interpretation, writing and preparation of the article, and the decision to submit the manuscript for publication. 